\title{
性，飼料条件および生育過程の異なるラットにおける 肝遊離アミノ酸濃度について*
}

大 沢猛, 中村加る, 矢島 和子, 西 郷 光 彦 東京農業大学

\section{On the Concentration of Free Amino Acids in Liver of Rats Different in Sex, Feeding Condition and Growing Stage \\ Takeshi Ōsawa, Kahoru Nakamura, Kazuko Yazima and Mitsuhiko Saigō \\ Tokyo University of Agriculture}

This study was undertaken to clarify the effects of difference in sex, feeding condition and growing stage on the concentration and pattern of free amino acids in the liver. The results were as follows:

1. Although female rats gave about $20 \%$ lower values for the concentrations of both essential and nonessential free amino acids in the liver compared with those of male rats, their percentage patterns were similar to each other. The concentrations of Glu, Tyr, Val, Ileu, Leu and Phe, were particularly lowered in female rats.

2. In rats receiving a protein free diet, the concentrations of Lys and His were elevated, but those of Val, Ileu, Leu and Phe were lowered compared with these values in rats receiving a standard diet. On the other hand, only Ser among non-essential amino acids was increased. The free amino acid pattern was remarkably different in the same way between the two groups.

In fasted rats, only Thr among essential amino acids and most of non-essential amino acids were much lowered. But the pattern for other amino acids was almost similar to that of the standard group.

3. Free amino acid concentration was changed in rats after growing as follows: (1) Thr and Ala were increased, (2) Ser, Glu, Gly, Cys, Met, Leu and Phe were decreased. Val, Ileu, Lys and His were almost unchanged.

Jap. J. Nutr., 34 (6) 263 270 (1976)

生体内に拈ける遊離アミノ酸変動に関する基礎的研究は, 血漿遊離アミノ酸を中心にして行われてきた。

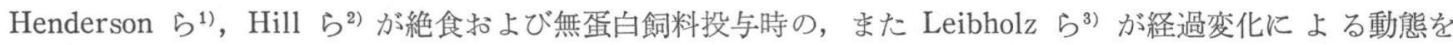
明らかにした。しかしながら，器官中の遊離アミノ酸の変動に関する基礎的研究は，少ない上うに思われる。 著者らは, 特に蛋白質代謝の要とも考兄られる肝臓の遊離アミノ酸の変動に着目し, 今回手初めに坴の基礎的 な研究として, 性別, 飼料条件拈よび生育過程に招ける変化を調べ, 今後の実験計画の参考ともなるべき若干 の知見を得たので報告する。ここにいう飼料条件とは, 無蛋白飼料並びに絶食を条件としたるのである。

\section{1. 性別による肝遊離アミノ酸の相違（実験 I ）}

実験方法 : 実験動物は， $80 \mathrm{~g}$ 前後のウィスター系ラットを用い，雄区，雌区の 2 区を設け，それぞれの区 を 5 匹ずつとし 5 日間飼育した。

* 肝遊離アミノ酸濃度に関する基礎的研究（第 1 報） 
飼料配合は表 1 に示寸通りであり, 飼料並びに水 は自由に摂取させた。

遊離アミノ酸は, 12 時間絶食後屠殺して肝臓を摘 出し，ピクリン酸による除蛋白汁液を用いてアミ， 酸自動分析器 (三田村理研アミノ酸自動分析器) に より定量した。

実験結果および考察 : 体重増加量並びに肝重量は, 表 2 预よび表 3 に示す通りである。

雌区は，雄区に比べ体重増加量並びに肝重量が僅

Table 2 Change in body weight in exp. I

\begin{tabular}{lr}
\hline Casein & 18.0 \\
Dextrin & 69.4 \\
Soybean oil & 8.0 \\
Mineral mixture* & 4.0 \\
Choline chloride & 0.1 \\
Vitamin mixture** & 0.5
\end{tabular}

* Mineral mixture : McCollum salt No. 185
** Vitamin mixture : Panvitan powder
(Takeda Chemical Ind., Ltd.)

(g)

\begin{tabular}{llccc}
\hline & Initial & Final & Gain & Gain/Day \\
\hline Male & $87 \pm 5.7^{*}$ & $111 \pm 8.1$ & $23 \pm 4.1$ & $4.6 \pm 0.8$ \\
Female & $83 \pm 5.7$ & $101 \pm 7.2$ & $19 \pm 4.9$ & $3.8 \pm 1.0$ \\
\hline
\end{tabular}

* Mean value \pm standard error

Table 3 Liver weight in exp. I $(\mathrm{g})$

Table 4 Concentration of free amino acids

$\begin{array}{cc}\text { Male } & \text { Female } \\ 4.2 \pm 0.6^{*} & 3.5 \pm 0.3\end{array}$

* Mean value \pm standard error

Table 5 Free amino acid pattern in liver of male and female rats

$(\%)$

\begin{tabular}{lrr}
\hline & \multicolumn{1}{c}{ Male } & \multicolumn{1}{c}{ Female } \\
\hline Asp & $8.4 \pm 1.2$ & $9.7 \pm 1.7(115)$ \\
Thr & $5.4 \pm 1.4$ & $4.9 \pm 1.8(91)$ \\
Ser & $8.3 \pm 2.0$ & $8.3 \pm 2.8(100)$ \\
Glu & $21.1 \pm 2.5$ & $19.9 \pm 3.4(94)$ \\
Pro & $0.8 \pm 0.4$ & $0.9 \pm 0.1(113)$ \\
Gly & $12.6 \pm 0.9$ & $13.1 \pm 3.1(104)$ \\
Ala & $14.5 \pm 3.1$ & $15.3 \pm 5.5(106)$ \\
Cys & $3.4 \pm 1.4$ & $2.4 \pm 0.9(71)$ \\
Val & $2.6 \pm 0.3$ & $2.5 \pm 0.5(96)$ \\
Met & $0.3 \pm 0.1$ & $0.2 \pm 0.2(67)$ \\
Ileu & $1.9 \pm 0.3$ & $1.7 \pm 0.2(89)$ \\
Leu & $3.3 \pm 0.5$ & $3.0 \pm 0.6(91)$ \\
Tyr & $1.6 \pm 0.5$ & $1.3 \pm 0.3(81)$ \\
Phe & $1.3 \pm 0.2$ & $1.1 \pm 0.2(85)$ \\
Lys & $13.5 \pm 1.6$ & $13.9 \pm 3.0(103)$ \\
His & $1.1 \pm 0.5$ & $1.9 \pm 0.9(173)$ \\
\hline
\end{tabular}

* Mean value \pm standard error

( ) : Female/male $\times 100$ in liver of male and female rats

$(\mathrm{mg} / 100 \mathrm{~g})$

\begin{tabular}{lrr}
\hline & \multicolumn{1}{c}{ Male } & \multicolumn{1}{c}{ Female } \\
\hline Asp & $10.7 \pm 1.9$ & $9.8 \pm 2.1(92)^{*}$ \\
Thr & $7.0 \pm 1.8$ & $4.9 \pm 1.8(70)$ \\
Ser & $10.6 \pm 2.7$ & $8.3 \pm 2.8(78)$ \\
Glu & $26.8 \pm 2.2$ & $20.1 \pm 3.9(75)^{* *}$ \\
Pro & $1.0 \pm 0.5$ & $0.9 \pm 0.1(90)$ \\
Gly & $16.2 \pm 1.7$ & $13.4 \pm 3.9(83)$ \\
Ala & $18.6 \pm 4.6$ & $15.1 \pm 4.5(81)$ \\
Cys & $4.5 \pm 1.9$ & $2.5 \pm 1.0(56)$ \\
Val & $3.3 \pm 0.4$ & $2.4 \pm 0.4(73)^{* *}$ \\
Met & $0.4 \pm 0.1$ & $0.2 \pm 0.1(50)^{* *}$ \\
Ileu & $2.4 \pm 0.3$ & $1.7 \pm 0.2(71)^{* * *}$ \\
Leu & $4.2 \pm 0.6$ & $2.9 \pm 0.5(69)^{* *}$ \\
Tyr & $2.1 \pm 0.7$ & $1.3 \pm 0.2(62)^{* *}$ \\
Phe & $1.7 \pm 0.2$ & $1.1 \pm 0.2(65)^{* * *}$ \\
Lys & $17.2 \pm 2.4$ & $14.2 \pm 4.0(83)$ \\
His & $1.4 \pm 0.7$ & $2.0 \pm 1.0(143)$ \\
\hline Total & $128.1 \pm 5.7$ & $100.9 \pm 7.1(79)^{* * *}$ \\
EAA & $37.5 \pm 3.3$ & $29.5 \pm 4.2(70)^{* * *}$ \\
NEAA & $90.5 \pm 5.4$ & $71.4 \pm 3.5(79)^{* * *}$ \\
E/N & $0.42 \pm 0.01$ & $0.41 \pm 0.01(98)$ \\
\hline
\end{tabular}

* Mean value \pm standard error

** Significantly different from male group at $\mathrm{P}<0.05$

*** Significantly different from male group at $\mathrm{P}<0.01$

( ) : Female $/$ male $\times 100$ 
かに低かった。しかし有意差が認められず両区の成長による差異が少いので，この飼育条件で，雌雄の性別に よる肝遊離アミノ酸濃度を比較することが可能なものと考えられる。

肝遊離アミノ酸濃度は, 表 4 亿示す通りである。

雌区は, 雄区に比べ全アミノ酸, 全不可欠アミノ酸, 扣よび全可欠アミノ酸の各濃度は同率 (79\%) で有意 に低い值を示した。個々のアミノ酸濃度についても不可火アミノ酸では, ほとんどのものが低い傾向を示し， 特に Val, Met, Ileu, Leu, Phe が有意に低く,Thr, Lys は有意の差はないが同様に低い傾向を示し，逆に His は有意の差はないが高い傾向を示した。可欠アミノ酸でも㴽とんどのアミノ酸が低い傾向を示し，特に Glu, Tyr が有意に低く, Asp, Ser, Pro, Gly, Ala, Cys は有意の差はないが低い傾向を示した。

以上のアミノ酸濃度を全肝臓中のアミノ酸含量で比較すると, 雌区の肝重量が小さいために上記の傾向がさ らに強く示され，Gly, Cys, Lys が有意の差をもって低い值を示した。

肝遊離アミノ酸濃度の百分率パターンは, 表 5 に示す通りである。

雌区は，雄区に比べ個々のアミノ酸についてほとんど差がなく，類似率4は は0.996を示したが，総じて雌区 の肝遊離アミノ酸濃度拈よび含量は, 雄区に比べ不可欠アミノ酸で Val, Ileu, Leu, Phe が有意に低く, 可欠 アミノ酸で Glu, Tyr が有意に低い值を示した。さらに他の不可欠, 可欠アミノ酸は, His 以外が低い值を 示す傾向にめった。

以上の結果から雌区は雄区に比べて多くのアミノ酸がそれぞれ添涩等しい割合で低い濃度を示しているのみ で, アミノ酸パターンには大きな差異はないものと思われる。

\section{2. 飼料条件の相違による肝遊離アミノ酸の变動（実験 II）}

実験動物は, $80 \mathrm{~g}$ 前後のウィスター系ラット雄を用い, 標準区, 無蛋白区, 絶食区の 3 区を設け, それぞれ の区を 5 匹ずつとし絶食区は 3 日間, 標準区, 無蛋白区はとれぞれ 5 日間飼育した。ここでの標準区は, 前記 表 1 の実験飼料と同一のものとし，無蛋白区は，標準区のカゼインをデキストリンに替えて使用した。

飼料並びに水は自由に摂取させた。

遊離アミノ酸の定量は, 前記の通りである。

実験結果および考察 : 体重増加量並びに肝重量は表 6 抢よび表 7 に示す通りである。

Table 6 Change in body weight in exp. II

(g)

\begin{tabular}{lcrrr}
\hline & Initial & \multicolumn{1}{c}{ Final } & \multicolumn{1}{c}{ Gain } & \multicolumn{1}{c}{ Gain/day } \\
\hline Standard** & $87 \pm 5.7^{*}$ & $111 \pm 8.1$ & $23 \pm 4.1$ & $4.6 \pm 0.8$ \\
Protein free** & $88 \pm 4.1$ & $78 \pm 2.9$ & $-10 \pm 2.0$ & $-2.0 \pm 0.4$ \\
Fast*** & $84 \pm 5.0$ & $63 \pm 3.8$ & $-21 \pm 3.2$ & $-6.9 \pm 1.1$ \\
\hline
\end{tabular}

* Mean value \pm standard error

** For 5 days

*** For 3 days

無蛋白区は，標準区に比べ体重増加量並びに肝重 量が有意に低下した。

絶食区も, 標準区に比べ体重増加量並びに肝重量 が有意に低下した。

Table 7 Liver weight in exp. II

(

\begin{tabular}{lcc}
\hline Standard & Protein free & Fast \\
\hline $4.2 \pm 0.6^{*}$ & $2.7 \pm 0.5$ & $2.5 \pm 0.3$ \\
\hline
\end{tabular}

* Mean value \pm standard error 
Table 8 Concentration of free amino acids in liver of rats under different feeding conditions

$(\mathrm{mg} / 100 \mathrm{~g})$

\begin{tabular}{|c|c|c|c|}
\hline & Standard & Protein free & Fast \\
\hline Asp & $10.7 \pm 1.9 *$ & $6.1 \pm 2.0^{* *}(57)$ & $4.3 \pm 2.0^{* * *}(40)$ \\
\hline Thr & $7.0 \pm 1.8$ & $4.5 \pm 2.3 \quad(64)$ & $2.4 \pm 1.0^{* * *}$ ( 34$)$ \\
\hline Ser & $10.6 \pm 2.7$ & $36.2 \pm 7.9^{* * *}(342)$ & $3.9 \pm 2.0^{* * *}(37)$ \\
\hline Glu & $26.8 \pm 2.2$ & $24.5 \pm 4.7 \quad(91)$ & $16.4 \pm 3.7^{* * *}$ ( 61$)$ \\
\hline Pro & $1.0 \pm 0.5$ & $0.8 \pm 0.3 \quad(80)$ & $1.6 \pm 0.8^{* * *}(160)$ \\
\hline Gly & $16.2 \pm 1.7$ & $15.4 \pm 2.0 \quad$ (95) & $10.7 \pm 1.6^{* * *}(66)$ \\
\hline Ala & $18.6 \pm 4.6$ & $15.4 \pm 3.4 \quad(83)$ & $10.8 \pm 1.2^{* *} \quad(58)$ \\
\hline Cys & $4.5 \pm 1.9$ & $1.3 \pm 0.1^{* * *}(29)$ & $1.2 \pm 0.9^{* *} \quad(27)$ \\
\hline Val & $3.3 \pm 0.4$ & 2. $0 \pm 0.5^{* * *}(61)$ & $4.5 \pm 2.3$ \\
\hline Met & $0.4 \pm 0.1$ & $0.2 \pm 0.1^{* *}(50)$ & $0.6 \pm 0.2$ \\
\hline Ileu & $2.4 \pm 0.3$ & $1.5 \pm 0.2^{* * *}(63)$ & $2.6 \pm 0.9$ \\
\hline Leu & $4.2 \pm 0.6$ & $2.7 \pm 0.2^{* * *}(64)$ & $4.6 \pm 1.9$ \\
\hline Tyr & $2.1 \pm 0.7$ & $1.3 \pm 0.2 \quad(62)$ & $1.5 \pm 0.1$ \\
\hline Phe & $1.7 \pm 0.2$ & $1.1 \pm 0.2^{* * *}(65)$ & $1.6 \pm 0.1$ \\
\hline Lys & $17.2 \pm 2.4$ & $22.6 \pm 3.6^{* *}(131)$ & $18.4 \pm 6.3$ \\
\hline His & $1.4 \pm 0.7$ & $3.4 \pm 1.3^{* *}(243)$ & $0.8 \pm 0.2$ \\
\hline Total & $128.7 \pm 5.7$ & $138.7 \pm 3.9 \quad$ & $85.2 \pm 18.2^{* * *}(67)$ \\
\hline EAA & $37.5 \pm 3.3$ & $38.1 \pm 5.3 \quad(102)$ & $35.5 \pm 11.6 \quad$ (95) \\
\hline NEEA & $90.5 \pm 5.4$ & $100.6 \pm 5.5^{* *}(111)$ & $49.7 \pm 7.6^{* * *}(55)$ \\
\hline $\mathrm{E} / \mathrm{N}$ & $0.42 \pm 0.01$ & $0.38 \pm 0.07 \quad(90)$ & $0.70 \pm 0.15^{* * *}(167)$ \\
\hline
\end{tabular}

* Mean value \pm standard error

** Significantly different from standard group at $\mathrm{P}<0.05$

*** Significantly different from standard group at $\mathrm{P}<0.01$

( ) : Protein free/standard $\times 100 \quad$ Fast $/$ standard $\times 100$

各区の肝遊離アミノ酸濃度は, 表 8 に示す通りである。

無蛋白区は，標準区に比べ全アミノ酸濃度㥂よび全不可欠アミノ酸濃度に差がなく, 全可欠アミノ酸濃度が 有意に上昇した。個々のアミノ酸濃度は, 不可欠アミノ酸で Lys, His が有意に上萛し, それ以外のアミノ酸 は低下傾向を示し, 特に Val, Met, Ileu, Leu, Phe が有意に低下した。可欠アミノ酸では Ser が著しく有 意に上昇し，それ以外のアミノ酸は低下傾向を示し，特に Asp, Cys が有意に低下した。これらのアミ, 酸 濃度の変動は，小島 ${ }^{5}$ ) の報告に類似している。また小島の報告にもあるように無蛋白質投与時に Ser 濃度が著 しく上升したことは, Ser 合成経路の酵素活性が上昇し ${ }^{6)}$, Ser 分解酵素 (Serin dehydratase) 活性が低下し だ)ことと関連するものと思われる。このことに関して著者ら ${ }^{8)}$ もた，低蛋白質投与時に肝中の Ser が上 升し，高蛋白質投与時に Ser が低下した結果を得ている。

絶食区は, 標準区に比べ全アミノ酸濃度拁よび全可欠アミノ酸濃度が有意に低下し, 全不可欠アミノ酸濃度 に差がみられなかった。その結果 $\mathrm{E} / \mathrm{N}$ 比が著しく有意に上昇している。個々のアミノ酸濃度については, 不 可欠アミノ酸で Thr が著しく有意に低下し, それ以外のアミノ酸は, 僅かに上昇傾向を示した。可欠アミ, 酸では, ほとんどのアミノ酸が低下傾向を示し，特に Asp, Ser, Glu, Gly, Ala, Cys が有意に低下した。こ れらは可欠アミノ酸が, エネルギー不足のために消費され，そのために低下したものではないかと思われる。

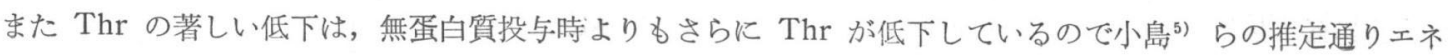


Table 9 Free amino acid pattern in liver of rats under different feeding conditions

$(\%)$

\begin{tabular}{|c|c|c|c|}
\hline & Standard & Protein free & Fast \\
\hline Asp & $8.4 \pm 1.2^{*}$ & $4.4 \pm 1.4^{* * *}(52)$ & $4.8 \pm 1.4^{* * *}(57)$ \\
\hline Thr & $5.4 \pm 1.4$ & $3.3 \pm 1.2^{* *}(61)$ & $2.8 \pm 1.0 * *(52)$ \\
\hline Ser & $8.3 \pm 2.0$ & $26.0 \pm 5.3$ & $4.8 \pm 2.6 \quad(58)$ \\
\hline Glu & $21.1 \pm 2.5$ & $17.6 \pm 3.3 \quad$ ( 83$)$ & $19.4 \pm 3.0 \quad(92)$ \\
\hline Pro & $0.8 \pm 0.4$ & $0.6 \pm 0.3 \quad(75)$ & $1.8 \pm 0.5$ \\
\hline Gly & $12.6 \pm 0.9$ & $11.1 \pm 1.4 \quad$ ( 88$)$ & $13.3 \pm 3.8 \quad(106)$ \\
\hline Ala & $14.5 \pm 3.1$ & $11.2 \pm 2.6$ & $12.4 \pm 1.4 \quad$ ( 86$)$ \\
\hline Cys & $3.4 \pm 1.4$ & $1.0 \pm 0.1 \quad$ (29) & $1.5 \pm 0.8$ \\
\hline Val & $2.6 \pm 0.3$ & $1.5 \pm 0.4 \quad(58)$ & $5.0 \pm 1.4 \quad$ (192) \\
\hline Met & $0.3 \pm 0.1$ & $0.1 \pm 0.1 \quad$ ( 33$)$ & $0.7 \pm 0.2 \quad$ (233) \\
\hline Ileu & $1.9 \pm 0.3$ & $1.1 \pm 0.1 \quad$ ( 58$)$ & $2.9 \pm 0.4 \quad$ (153) \\
\hline Leu & $3.3 \pm 0.5$ & $1.9 \pm 0.1 \quad(58)$ & $5.2 \pm 1.1 \quad$ (158) \\
\hline Tyr & $1.6 \pm 0.5$ & $1.0 \pm 0.1 \quad$ (63) & $1.9 \pm 0.5$ \\
\hline Phe & $1.3 \pm 0.2$ & $0.8 \pm 0.1 \quad(62)$ & $2.0 \pm 0.4 \quad$ (154) \\
\hline Lys & $13.5 \pm 1.6$ & $16.3 \pm 2.4 \quad(120)$ & $21.4 \pm 3.7 \quad$ (159) \\
\hline His & $1.1 \pm 0.5$ & $2.4 \pm 0.9 \quad$ & $0.9 \pm 0.2$ \\
\hline
\end{tabular}

* Mean value \pm standard error

** Significantly different from standard group at $\mathrm{P}<0.05$

*** Significantly difierent from standard group at $\mathrm{P}<0.01$

( ) : Protein free/standard $\times 100 \quad$ Fast $/$ standard $\times 100$

ルギー不足と関係があるように思われる。

無蛋白区と絶食区との比較は, 飼育日数に打いて相違するので一律の評価は難しいが, 肝遊離アミノ酸の Ser, Pro, Val, Met, Ileu, Leu, His 濃度が様相を異にすることが示された。

肝遊離アミノ酸パターンは, 表 9 に示す通りである。

無蛋白区は, 標準区に比べ Ser が上我し, Asp, Thr, Gly が有意に低下した。その他のアミノ酸は, 有意 の差はみられなかった。

この類似率を求めてみると 0.808 で肝遊離アミノ酸パターンには相当の相違があり, Ser を除いた類似率を 求めてみると0.976で標準区の值に近づくことから, このパターンの相違は主に Ser の著しい上身によると考 えられる。

絶食区は, 標準区に比べ Val, Lys が有意に上昇し, Asp, Thr が有意に低下したが, その他のアミノ酸に

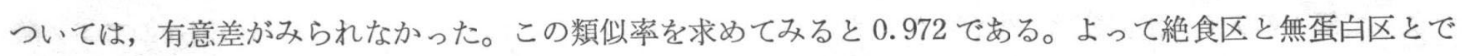
は, 肝遊離アミノ酸パターンに批いて絶食区の方が標準区に近似する結果となっている。

\section{3. 生育過程による肝遊離アミノ酸の変動（実験III）}

実験方法 : 実験動物は, $90 \mathrm{~g}$ 前後のウィスター系ラット雄を用い.90日間飼育の変化を求めた。 飼料は, 固型飼料 (MF)（オリエンタル酵母 K. K) を用い, 飼料並びに水は自由に摂取させた。 ラットを 5 匹ずつ 0 日区，30日区，60日区，90日区の 4 区を設定し，屠殺直前に12時間絶食させ肝遊離アミ ノ酸濃度を測定した。遊離アミノ酸の定量方法は, 前記の通りである。

実験結果および考察：30日間隔の体重変化は，図 1 と示す通りである。 


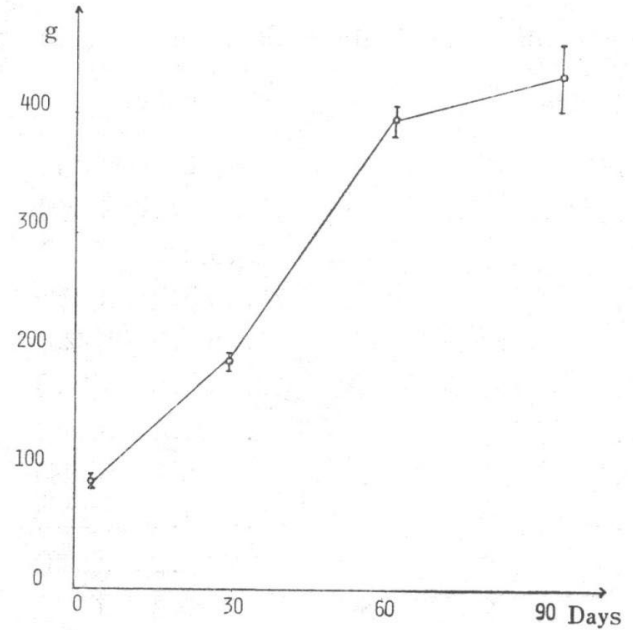

Fig. 1 Change in body weight in exp. II

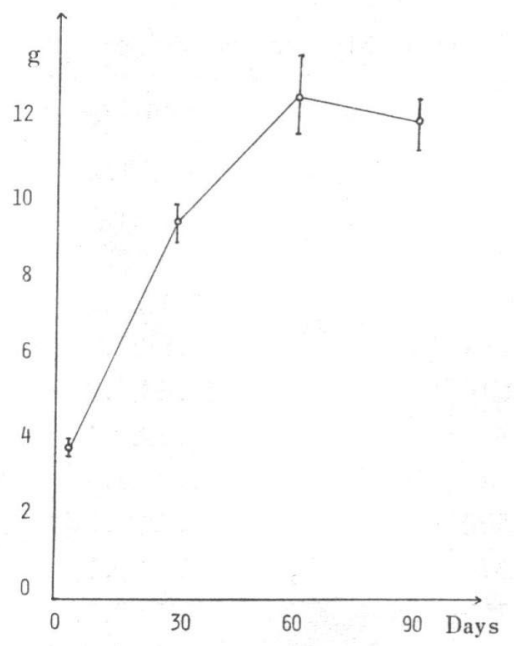

Fig. 2 Change in liver weight in exp. III

即ち平均体重では実験開始 0 日は $94 \mathrm{~g}, 30$ 日後は $280 \mathrm{~g}, 60$ 日後は $380 \mathrm{~g}, 90$ 日後は $417 \mathrm{~g}$, であり, 60 日 以降の体重増加は著しく低下した。体重の変動湢を考虑すると，60日以降はほほ成熟期に達しているものと考 えられる。

30 日間隔の肝臟重量の変化は, 図 2 に示す通りである。

即ち実験開始 0 日は $3.9 \mathrm{~g}, 30$ 日後は $9.5 \mathrm{~g}, 60$ 日後は $12.7 \mathrm{~g}, 90$ 日後は $12.1 \mathrm{~g}$ となり, 60 日以降は増加がみ られなかった。また体重に対する割合でみると，0日は，4.1\%，30日は3.4\%，60日は3.3\%，90日は2.9\%と なり, 経日に伴い低下傾向を示した。

30 日間隔の肝遊離アミノ酸濃度は, 表10に示す通りである。

30日後には，0日に比べ全アミノ酸, 全不可欠アミノ酸拈よび全可欠アミノ酸の各濃度に差がみられなかっ た。個々のアミノ酸濃度をみてもほとんどのアミノ酸で差がなく, Ser のみが有意に低下しているのが目立っ た。

60 日後に打いても，0日に比べ全アミノ酸，全不可欠アミノ酸拈よび全可欠アミノ酸の各濃度に差がなかっ た。しかし個々のアミノ酸濃度をみると Glu, Gly, Cys が有意に低下し Ala が有意に上䄯した。

90 日後には, 0 日に比べ全アミノ酸濃度枋上び全可欠アミノ酸濃度が有意に低下し, 全不可欠アミノ酸濃度 は, 有意の差はないが低下傾向を示した。個々のアミノ酸濃度をみると Thr, Ala が有意に上升し, Ser, Glu, Gly, Cys, Met, Leu, Phe が有意に低下した。

よって個々のアミノ酸濃度は, 生育に伴い大きく変動するものと思われる。さらにこれらの個々のアミノ酸 を成長期（0，30日区）と成熟期（60，90日区）とにわけて比較すると成熟期は，成長期に比べ Thr, Alaが 上年し, Ser, Glu, Gly, Cys, Met, Leu, Phe が低下し，Val, Ileu, Lys, His は変動が少ない上うに思われ る。

30日間隔の肝遊離アミノ酸パターンは, 表11の通りである。

30日区は，0 日区に比べパターンに変化がなく，類似率を求めると $0.996 て ゙ 0$ 日の值に近似していた。

60 日区は，0 日区に比べ Asp, Ala が有意に上梨し，Glu, Gly が有意に低下している。類似率を求めてみ ると0.898でパターンの相違が生じていた。

90 日区は，0 日区に比べ Thr, Ala が有意に上昇し，Ser, Gly が有意に低下した。この類似率を求めてみ 
Table 10 Concentration of free amino acids in liver of rats in different growing stages (mg/100 g)

\begin{tabular}{lcccc} 
& 0 & 30 & 60 & 90 (days) \\
\hline Asp & $3.8 \pm 1.3^{*}$ & $2.2 \pm 0.9$ & $7.1 \pm 2.5$ & $3.2 \pm 1.0$ \\
Thr & $2.5 \pm 0.7$ & $2.7 \pm 1.3$ & $4.2 \pm 1.4$ & $6.1 \pm 2.0^{* *}$ \\
Ser & $5.5 \pm 1.2$ & $3.0 \pm 0.6^{* *}$ & $3.2 \pm 2.4$ & $1.4 \pm 0.8^{* *}$ \\
Glu & $23.2 \pm 3.0$ & $23.6 \pm 3.1$ & $16.9 \pm 2.5^{* *}$ & $16.1 \pm 3.8^{* *}$ \\
Gly & $14.9 \pm 2.1$ & $14.4 \pm 2.1$ & $8.8 \pm 1.1^{* *}$ & $10.3 \pm 0.8^{* *}$ \\
Ala & $8.3 \pm 1.2$ & $10.4 \pm 6.0$ & $19.1 \pm 3.8^{* *}$ & $13.9 \pm 1.7^{* *}$ \\
Cys & $1.1 \pm 0.1$ & $1.0 \pm 0.4$ & $0.4 \pm 0.2^{* *}$ & $0.2 \pm 0.1^{* *}$ \\
Val & $4.6 \pm 1.0$ & $3.6 \pm 0.8$ & $4.0 \pm 0.6$ & $3.2 \pm 0.9$ \\
Met & $1.0 \pm 0.3$ & $1.0 \pm 0.2$ & $0.6 \pm 0.3$ & $0.4 \pm 0.1^{* *}$ \\
Ileu & $2.2 \pm 0.4$ & $1.8 \pm 0.3$ & $1.9 \pm 0.3$ & $1.7 \pm 0.3$ \\
Leu & $4.5 \pm 0.9$ & $4.5 \pm 1.4$ & $3.5 \pm 0.8$ & $3.3 \pm 0.5^{* *}$ \\
Tyr & $1.7 \pm 0.5$ & $1.5 \pm 0.6$ & $1.7 \pm 0.6$ & $1.2 \pm 0.3$ \\
Phe & $2.1 \pm 0.3$ & $2.0 \pm 0.5$ & $1.8 \pm 0.8$ & $1.3 \pm 0.3^{* *}$ \\
Lys & $11.6 \pm 2.4$ & $9.7 \pm 2.4$ & $9.8 \pm 1.1$ & $8.6 \pm 1.6$ \\
His & $3.9 \pm 1.3$ & $4.6 \pm 1.0$ & $3.8 \pm 0.2$ & $3.9 \pm 0.7$ \\
\hline Total & $90.9 \pm 3.0$ & $86.0 \pm 7.3$ & $89.0 \pm 10.4$ & $74.9 \pm 4.8^{* *}$ \\
EAA & $32.4 \pm 2.9$ & $29.9 \pm 5.6$ & $29.5 \pm 5.3$ & $28.4 \pm 4.3$ \\
NEAA & $58.5 \pm 2.7$ & $56.1 \pm 9.0$ & $57.2 \pm 4.9$ & $46.5 \pm 4.4^{* *}$ \\
E/N & $0.55 \pm 0.06$ & $0.56 \pm 0.19$ & $0.51 \pm 0.05$ & $0.62 \pm 0.12$ \\
\hline$*$ MA & & & \\
\hline
\end{tabular}

* Mean value \pm standard error

** Significantly different from 0 day group at $\mathrm{P}<0.05$

Table 11 Free amino acid pattern in liver of rats in different growing stages

\begin{tabular}{lrrrc}
\hline & \multicolumn{1}{c}{0} & \multicolumn{1}{c}{30} & 60 & 90 (days) \\
\hline Asp & $4.2 \pm 1.4^{*}$ & $2.6 \pm 1.0$ & $8.0 \pm 2.1$ & $4.5 \pm 1.1$ \\
Thr & $2.8 \pm 0.7$ & $2.5 \pm 1.4$ & $4.8 \pm 1.3$ & $8.0 \pm 2.2^{* *}$ \\
Ser & $6.1 \pm 1.3$ & $3.5 \pm 0.6$ & $3.4 \pm 2.2$ & $1.9 \pm 1.1^{* *}$ \\
Glu & $25.5 \pm 2.9$ & $27.4 \pm 2.6$ & $19.5 \pm 1.4^{* *}$ & $21.4 \pm 4.6$ \\
Gly & $16.4 \pm 2.4$ & $16.7 \pm 2.3$ & $10.1 \pm 0.9$ & $13.4 \pm 1.1^{* *}$ \\
Ala & $9.1 \pm 1.4$ & $11.9 \pm 6.7$ & $22.4 \pm 6.3^{* *}$ & $18.6 \pm 1.8^{* *}$ \\
Cys & $1.2 \pm 0.2$ & $1.2 \pm 0.4$ & $0.5 \pm 0.3$ & $0.3 \pm 0.2$ \\
Val & $5.1 \pm 0.9$ & $4.1 \pm 0.9$ & $4.6 \pm 0.6$ & $4.2 \pm 1.1$ \\
Met & $1.1 \pm 0.3$ & $1.2 \pm 0.3$ & $0.7 \pm 0.3$ & $0.5 \pm 0.1$ \\
Ileu & $2.5 \pm 0.5$ & $2.1 \pm 0.4$ & $2.2 \pm 0.1$ & $2.2 \pm 0.3$ \\
Leu & $4.9 \pm 0.7$ & $5.2 \pm 1.6$ & $4.0 \pm 0.7$ & $4.4 \pm 0.6$ \\
Tyr & $1.9 \pm 0.4$ & $1.7 \pm 0.6$ & $1.9 \pm 0.6$ & $1.6 \pm 0.3$ \\
Phe & $2.3 \pm 0.3$ & $2.3 \pm 0.6$ & $2.0 \pm 0.7$ & $1.7 \pm 0.4$ \\
Lys & $12.7 \pm 2.7$ & $11.5 \pm 3.4$ & $11.2 \pm 1.6$ & $11.4 \pm 2.4$ \\
His & $4.3 \pm 1.5$ & $5.4 \pm 1.3$ & $4.4 \pm 0.3$ & $5.1 \pm 0.8$ \\
\hline
\end{tabular}

* Mean value \pm standard error

** Significantly different from 0 day group at $\mathrm{P}<0.05$ 
ると0.930となり60日区ょり0日区の值に近似していた。

以上の結果から, 生育過程に扮ける成長期と成熟期の肝遊離アミノ酸濃度招よびパターンは, かなり様相を 異にするものと思われ, 今後長期間の実験計画は, 当然のことながら成長期と成熟期とにわけて研究を進める べきであると思われる。また成熟期に Thr と Ala 濃度が著しく上昇した理由はわからないが, 体重増加が ほとんぞみられなくなったこととの関係について今後追究していきたいと考㝋る。

\section{要 約}

肝遊離アミノ酸の性別, 飼料条件扰よび生育過程に打ける变化を明らかにし, 次の結果を得た。

1. 性の相違について

雌区は，雄区に比べ全不可欠アミノ酸濃度扣よび全可欠アミノ酸濃度はいずれも平行的に低く, 個々のアミ ノ酸濃度ではそれぞれ20\%ぐらい低かったが，特にGlu，Tyr，Val，Met, Ileu, Leu, Pheが有意に低かった。 またアミノ酸パターンは, 雌区, 雄区ともほほ近似していた。

2. 飼料条件の相違について

無蛋白区は，標準区に比べ不可欠アミノ酸濃度で Lys, His が上昇し, Val, Ileu, Leu, Phe が低下した。 可欠アミノ酸では, Ser が著しく上犁した。またパターンでは, Ser の著しい上昇を中心に異った様相を呈し た。

絶食区は, 標準区に比べ不可欠アミノ酸濃度でThr のみが著しく低下した。これに対し可欠アミノ酸濃度 はほほとんどのアミノ酸が低下していた。京た両者のパターンは，ほぽ近似していた。

3. 成育過程に怙ける変化について

成熟期のアミノ酸濃度は, 成長期に比べ, 増減が大きくなる傾向にあり, 個々のアミノ酸濃度の増隇の特長 は, 次の通りであった。

(1) 上昇したアミノ酸は, Thr, Ala

(2) 低下したアミノ酸は, Ser, Glu, Gly, Cys, Met, Leu, Phe

(3) 変動の少いアミノ酸は, Val, Ileu, Lys, His

文献

1) Henderson, L. M., Schurr, P. E. and Elvehjem, C. A. : J. Biol. Chem., 177, 815 (1949)

2) Hill, D. C. and Olsen, E. M. : J. Nutr., 79, 303 (1963)

3) Leibholz, J., Australian J. : Agr, Res., 17, 237 (1966)

4）田村真八郎，大沢文子：栄養と食糧, 22, 494 (1969)

5) 小島光恵 : 生化学, 45, 137 (1973)

6) Fallon, H. J., Hockney, E. J., Byrne, W. L. : J. Biol. Chem., 241, 4157 (1966)

7) Pitot, H. C., Potter, V. R., Morris, H. P. : Cancer Res., 21, 1001 (1961)

8）大沢 猛, 中村かほる, 矢島和子, 西郷光彦: 東京農業大学農学集報, 20, 43 (1975)

（受付 : 昭和51年11月15日） 